\title{
Autoantibody profiles in the sera of patients with $Q$ fever: characterization of antigens by immunofluorescence, immunoblot and sequence analysis
}

\author{
MT Camacho', I Outschoorn², A Tellez ${ }^{1}$ and J Sequí*3
}

\begin{abstract}
Address: ${ }^{1}$ Departamento de Orientación Diagnóstica. Centro Nacional de Microbiologia. Instituto de Salud Carlos III. Ctra. Majadahonda 10. 28029-Madrid. Spain

Email: MT Camacho - mtcamacho@eresmas.com; I Outschoorn - ioutscho@isciii.es; A Tellez - atellez@isciii.es;

J Sequí* - jsequi.hciii@salud.madrid.org

* Corresponding author
\end{abstract} Pozuelo Km 12,5. 28080-Madrid. Spain, ${ }^{2}$ Departamento de Respuesta Inmune. Centro Nacional de Microbiologia. Instituto de Salud Carlos III. Ctra. Majadahonda -Pozuelo Km 12,5. 28080-Madrid. Spain and ${ }^{3}$ Servicio de Inmunología. Hospital Carlos III. Imsalud. c/ Sinesio Delgado n ${ }^{\circ}$

Published: 10 November 2005

Journal of Autoimmune Diseases 2005, 2:10 doi:10.1186/1740-2557-2-10

This article is available from: http://www.jautoimdis.com/content/2/1/10

(C) 2005 Camacho et al; licensee BioMed Central Ltd.

This is an Open Access article distributed under the terms of the Creative Commons Attribution License (http://creativecommons.org/licenses/by/2.0), which permits unrestricted use, distribution, and reproduction in any medium, provided the original work is properly cited.
Received: 04 April 2005

Accepted: 10 November 2005

\begin{abstract}
Recent reports have shown that some of the immunological aspects of $Q$ fever, a rickettsiosis caused by Coxiella burnetii, could be related to self-antigen responses. The aim of this study was to determine the specificity of the autoantibody response of patients with acute and chronic Coxiella infections. Smooth muscle and cardiac muscle-specific autoantibodies were observed in significant percentages in acutely or chronically affected $Q$ fever patients when compared to healthy volunteers. Moreover, the incidence of cardiac muscle-specific autoantibody was significantly higher among chronically ill patients compared to acutely ill patients. Moreover, a band of $50 \mathrm{kD}$ of a HeLa extract was detected in most of the sera of individuals with chronic infections and previous sequence analysis suggests that this antigen presents a high degree of homology with the human actin elongation factor I alpha. Further research would be necessary to confirm if antibodies to human cytoskeletal proteins could be of clinical importance in chronically infected $\mathrm{Q}$ fever patients.
\end{abstract}

\section{Background}

$\mathrm{Q}$ fever is a worldwide distributed human rickettsiosis that was described by Derrick in 1937. Burnett in Australia and Cox in the United States first isolated its etiological agent almost simultaneously so it was referred to as Coxiella burnetii $[1,2]$. Q fever infection is usually asymptomatic or acute self-limited but Coxiella is an intracellular bacterium that may persist within host macrophages leading to chronic complications such as endocarditis, hepatitis, meningitis, bone infections or chronic fatigue syndrome [3-6]. Diagnosis of Q fever is usually based on serological procedures because isolation of the bacterium is difficult and hazardous and requires level 3 biosafety laboratories [7]. Unique to Coxiella is its antigenic phase variation that appears to involve changes on lipopolyssacharide $[2,4,8]$. Virulent phase I bacteria are isolated from natural infection while avirulent phase II occurs after serial passages. Although the factors that determine the clinical presentation of $\mathrm{Q}$ fever are still not well understood, variation in C. burnetii strains, route of infection, 
Table I: Distribution of patients with acute and chronic $Q$ fever that showed specific autoantibodies (IgG isotype) by indirect immunofluorescence.

\begin{tabular}{lcc}
\hline Specific autoantibodies & $\begin{array}{c}\text { Acute } \mathrm{Q} \text { fever } \\
(\mathrm{n}=24)(\%)\end{array}$ & $\begin{array}{c}\text { Chronic } \mathrm{Q} \text { fever } \\
(\mathrm{n}=34)(\%)\end{array}$ \\
\hline ANA & $3(12.5)$ & $5(14.7)$ \\
dsDNA & $1(4.1)$ & $3(8.8)$ \\
ANCA & $3(12.5)$ & $4(11.8)$ \\
ASMA & $7(29.2)^{*}$ & $9(26.5)^{*}$ \\
PCA & 0 & $3(8.8)$ \\
CMA & $3(12.1)^{*}$ & $13(38.3) \#$ \\
\hline Total positive patients & $13(54.2)$ & $23(67.6)$ \\
\hline
\end{tabular}

ANA: Anti-nuclear antibodies;

dsDNA: Anti-double strand DNA antibodies;

ANCA: Anti-neutrophil antibodies;

ASMA: Anti-smooth muscle antibodies;

PCA: Anti-parietal cells antibodies;

CMA: Anti-cardiac muscle antibodies.

*: $\mathrm{p}<0.05$ as compared with healthy controls

$\#: p<0.05$ as compared with acute $Q$ fever patients and healthy

controls

host immunity and size of the inoculum have been implicated in disease evolution $[2,4,5]$.

Autoimmune diseases are defined as the pathologic sequelae of autoimmune responses. The precise mechanisms by which they are induced are still under discussion, but genetic, hormonal and environmental factors have all been implicated $[9,10]$. The idea that infectious agents may represent one of the major environmental factors initiating autoimmune responses is now generally accepted and the mechanisms of induction are currently being re-examined [11-13]. Intracellular microorganisms, particularly those associated with persistent or latent infection, have developed strategies to modulate immune responses and hence survive within host cells [14]. Under these circumstances, these microorganisms would not only initiate but also sustain an anomalous reaction that would lead to the appearance of autoimmune features in predisposed patients. Molecular homology with host sequences, polyclonal stimulation of $\mathrm{B}$ and $\mathrm{T}$ clones, cytokine stimulation, over expression of major histocompatibility complex molecules (MHC II), antigen modification and host cell damage with the release of self-antigens, are the most commonly described mechanisms that could lead to autoimmune responses due to infectious agents $[11,13,15-17]$. Links between autoimmunity and infection have been described in several situations, as in the case of myocarditis following coxsackievirus and trypanosomal infections [18-20], rheumatic fever in relation to streptococci [21], ankylosing spondylitis and klebsiella
[22], reactive arthropathies and Epstein Barr viruses $[23,24]$ and recently heart disease and chlamydia [25]. Direct evidence that confirms the diagnosis of autoimmune diseases requires test that are still beyond the capacity of most clinical laboratories so autoimmune disease diagnosis is frequently based on circumstantial evidence [26], such as the demonstration and quantitation of the various autoantibodies.

In $\mathrm{Q}$ fever patients, the immune responses elicited by $C$. burnetii are associated with inflammatory responses, rheumatoid factor, cryoglobulins or immune-complexes $[8,27]$. Antibodies to cardiolipin, nuclear antigens, leukocyte, platelet, mitochondrial and smooth muscle antigens are commonly found in chronically infected patients $[1,8,27]$. The study of IgG subclass distributions has revealed a significant increase in IgG1 and IgG3 levels in sera of patients similarly to those described in some autoimmune diseases [28]. Based on all these findings it could be proposed that some pathological aspects of the long-term chronic Q fever disease, such as heart disease, could be induced or maintained by autoimmune mechanisms. The aim of this study was to characterize the specificity of the autoantigens recognised by circulating antibodies in sera of patients with acute and chronic Coxiella infections and identify differences between chronic diseases with and without cardiac involvement. This may bring new insights to the mechanisms of induction of possible auto-reactive cardiac complications.

\section{Methods \\ Study Subjects}

The work was done in accordance with the regulations of internal review board of the Institute of Health, Carlos III. Spain. The patients and volunteers gave a written informed consent on the use of their sera to participate in the study, which was approved by the Human Research Committee.

Serum samples of patients with Q fever. Convalescent sera from 58 serologically confirmed acute $(\mathrm{n}=24)$ and chronic ( $\mathrm{n}=34) \mathrm{Q}$ fever cases were studied. All patients were adults, equally divided between males and females, aged 26 - 60 years (mean 45 years). Diagnosis was done by immunofluorescence using phase I and phase II Coxiella antigens. A serum sample with phase II IgG titre $\geq$ 200 and phase II IgM $\geq 50$ was considered acute and a serum sample with a phase I IgG titre $\geq 800$ was classified as chronic [1,2]. All chronic cases had phase I IgA antibodies titre $\geq 50$ [29]. Patients with acute infection had fever and/or atypical pneumonia but those demonstrating serological evidence of chronic Q fever disease could be divided in two groups: those with cardiac involvement ( $\mathrm{n}$ $=26$ ) or those with other pathologies (hepatic diseases, fever or bone disease) $(n=8)$. 


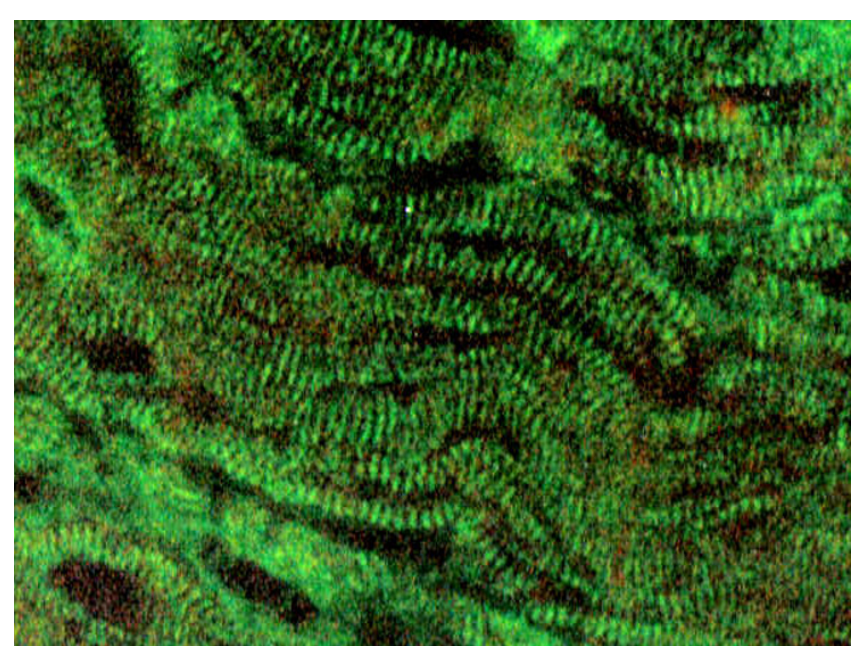

Figure I

Fibrillar indirect immunofluorescence stain with obtained with sera of $Q$ fever patients using monkey cardiac muscle sections. Magnification $\times 400$.

\section{Normal control group}

Twenty serum samples from healthy volunteers were studied, (males 10, females 10) aged 18 - 36 years (mean 29 years).

\section{Detection of autoantibodies by indirect immunofluorescence (IIF)}

Cryostat sections of monkey cardiac muscle (The Binding Site, UK) were used as a substrate to determine cardiac muscle antibodies (CMA). Sections of rat liver, kidney or stomach (BioSystems, Sp) were used as a substrate to detect specific antibodies (anti-parietal cell, PCA, and anti-smooth muscle, ASMA). Human carcinoma cell line (Hep-2) (MarDx Carlsbad, USA) was used as a substrate to study anti-nuclear antibodies (ANA). Anti-neutrophil antibodies (ANCA) were screened using neutrophil slides (The Binding Site, UK) and anti-double-stranded DNA antibodies (dsDNA) were assayed using Crithidia luciliae slides (MarDx Carlsbad, USA).

IIF was done as previously described [30]. Briefly, sera of patients were diluted in phosphate buffered saline (PBS) pH 7.4 (1:40 in ANCA and Hep-2 slides, 1:20 in CMA, dsDNA and rat liver, kidney and stomach slides) and incubated for $30 \mathrm{~min}$ at room temperature with each of the sections. Bound antibodies were detected with a fluorescent rabbit anti-human IgG immunoglobulin (Dako, DK). After each incubation, the slides were washed three times for five minutes with PBS. After the final wash, the slides were mounted in 70\% glycerol in PBS and examined in a Leitz Diaplan fluorescence microscope. Slides were coded and scored blind by two independent examiners.

\section{Detection of HeLa antigens specific autoantibodies by Western blot}

Assay was carried out using methods previously described $[31,32]$. Briefly, HeLa cells were cultured at $37^{\circ} \mathrm{C}$ in $5 \%$ CO2 to logarithmic phase in RPMI 1640 supplemented with $10 \%$ heat inactivated fetal calf serum, $1 \%$ glutamin, $10 \mathrm{U} / \mathrm{ml}$ penicillin and $60 \mu \mathrm{g} / \mathrm{ml}$ streptomycin. Then, the cells were incubated for $30 \mathrm{~min}$ at $4{ }^{\circ} \mathrm{C}$ in lysis buffer $(1 \%$ Nonidet P-40, $150 \mathrm{mM} \mathrm{NaCl}, 20 \mathrm{mM}$ Tris-HCl pH 8, 1 $\mathrm{mM}$ phenylmethylsulfonyl fluoride, $1 \mu / \mathrm{ml}$ aprotinin, 1 $\mu / \mathrm{ml}$ pepstatin, $1 \mu / \mathrm{ml}$ leupeptin and $2 \mathrm{mM}$ EDTA). After centrifugation at $20,000 \times \mathrm{g}$ for $30 \mathrm{~min}$, the supernatants were stored at $-80^{\circ} \mathrm{C}$. Protein concentration was determined by BCA assay (Pierce, Pennsylvania, USA). About $400 \mu \mathrm{g}$ of HeLa whole cell extracts were separated on 12 $\%$ SDS-PAGE. Proteins were electrotransferred to polyvinyl difluoride (PVDF) or nitrocellulose membranes in a semi-dry system for $1 \mathrm{~h}$ at $5.5 \mathrm{~mA} / \mathrm{cm} 2$ in carbonate buffer, however ethanol $20 \%(\mathrm{v} / \mathrm{v})$ was added instead of methanol. Membranes were soaked for 1 hour in PBS-5\% bovine serum albumin (BSA) and incubated overnight with sera diluted 1:100 in PBS-BSA. After washing, the membranes were incubated for 1 hour with an alkaline phosphatase-conjugated anti-human IgG antibody (The Binding Site. UK) at 1:8000 dilution. After three washes, antigen-bound antibody was visualised with nitroblue tetrazolium and 5-bromo-4chloro-3-indolyl phosphate (Bio-Rad, Richmond, CA) following manufacturer's instructions.

\section{Protein isolation and $\mathbf{N}$-terminal sequence analysis}

HeLa proteins were separated by $8 \%$ SDS-PAGE and electrotransferred to PVDF membranes as described above. The membranes were then stained with Coomassie Brilliant Blue R-250 and destained in $50 \%$ methanol. The proteins of interest were cut out from the air-dried membrane and incubated for 30 min with $0.5 \%$ polivinilpirrolidone-40 in $100 \mathrm{mM}$ acetic acid, digested at a enzymesubstrate ratio 1:20 in weight with trypsin in $100 \mathrm{mM}$ sodium bicarbonate at $\mathrm{pH} 8.2$, and then incubated in acetonitrile $95: 5(\mathrm{v} / \mathrm{v})$ for 16 hours at $37^{\circ} \mathrm{C}$. After centrifugation at $12.000 \times \mathrm{g}$ for $10 \mathrm{~min}$ the digestion mixture was acidified with $2 \%$ trifluoroacetic acid and the supernatant injected in a C18 Vydac $2.1 \times 250 \mathrm{~mm}$ microbore column (Beckman HPLC "System Gold") at a flow rate of $0.15 \mathrm{ml} /$ min in a chromatographic gradient of $7 \%$ acetonitrile and $0.09 \%$ of trifluoroacetic acid in water. For peptide microsequencing a pulse liquid phase automatic sequencer was used (Applied Biosystems model 473). Sequence homologies obtained with the other proteins were analysed with FASTA and TFASTA programs using the update database from Swissprotein and GenEMBL. 
Acute Q fever Patients

$\begin{array}{lllllll}1 & 5 & 6 & 10 & 15 & 20 & 24\end{array}$
Chronic Q fever Patients

$\begin{array}{llllllllll}2 & 7 & 10 & 11 & 15 & 22 & 27 & 28 & 31 & 32\end{array}$

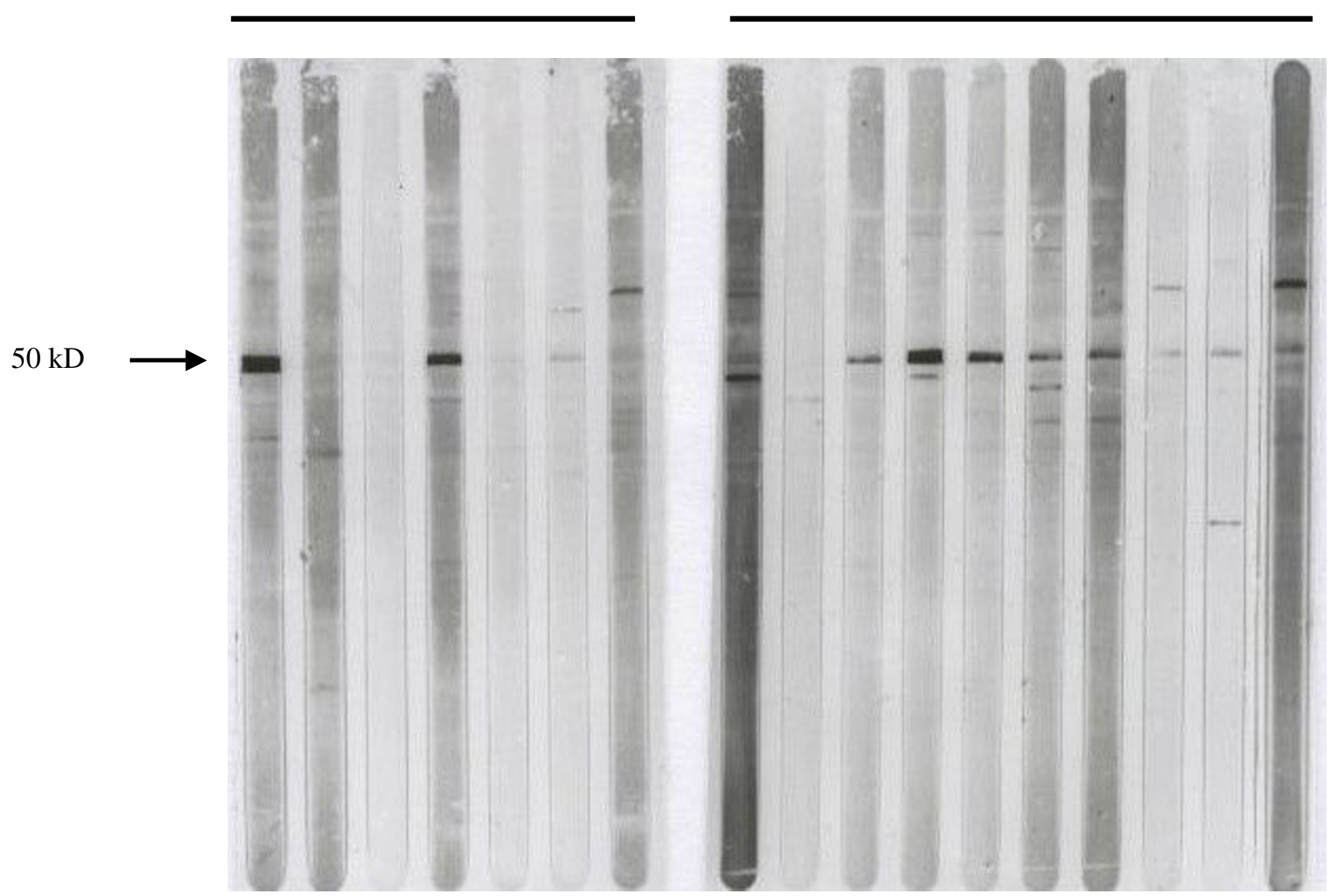

Figure 2

IgG antibodies detected in sera of $Q$ fever patients against partially purified HeLa cell antigens by Western blot analysis. Incubated with sera from acute (number. I,5,6, I0, I5,20,24) and chronic (number: 2,7,I0,II, I5,22,27,28,31,32) Q fever patients. Results obtained with representative sera from each group are depicted. Location of the $50 \mathrm{kD}$ bands are indicated.

\section{Data analysis}

The results of IIF were analysed using Fisher's exact test whenever appropriate. The overall difference was considered significant when $\mathrm{p}<0.05$.

\section{Results}

\section{Detection of autoantibodies by IIF}

The substrate specific responses detected in sera of patients with acute and chronic Q fever infections are shown in Table 1.

A total of $54.2 \%$ of patients with acute infection had demonstrable responses to at least one of the antigens tested. One patient had antibodies to dsDNA and three had ANCA or ANA but only ASMA and CMA were detect- able in a significant number of patients $(29.2 \%$ and $12.1 \%$ respectively).

On the other hand, $67.2 \%$ of the patients with chronic Q fever infections showed positive results by IIF, most of them to various antigens tested and no differences were found between patients with or without cardiac involvement. Three patients $(8.8 \%)$ elicited antibodies to dsDNA or parietal cells, four had ANCA (11.8\%) and five ANA $(14.7 \%)$, and, as in acute patients, the presence of ASMA was detected in a significantly higher percentage of sera (26.5\%). CMA were found in 13 patients (38.3\%) and both fibrillar and sarcolemma fluorescence stains were found (figure 1). The high frequency of CMA-specific antibody response detected on chronically infected patients 
>gi|4503471|ref|NP_001393.1| eukaryotic translation elongation factor 1 alpha 1 [Homo sapiens]

MGKEKTHINIVVIGHVDSGKSTTTGHLIYKCGGIDKRTIEKFEKEAAEMGKGSFKYAWVLDKLKAERERG

ITIDISLWKFETSKYYVTI IDAPGHRDF IKNMITGTSQADCAVLIVAAGVGEFEAGISKNGQTREHALLA

YTLGVKQLIVGVNKMDSTEPPYSQKRYEEIVKEVSTYIKKIGYNPDTVAFVP ISGWNGDNMLEP SANMPW

Sequence from fraction 35 ETGTLKPGM

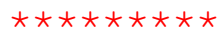

FKGWKVTRKDGNASGTTLLEALDCILPPTRPTDKPLRLPLQDVYKIGGIGTVPVGRVETGVLKPGMVTTF

APVNVTTEVKSVEMHHEALSEALPGDNVGFNVKNVSVKDVRRGNVAGDSKNDPPMEAAGFTAQVIILNHP

GQISAGYAPVLDCHTAHIACKFAELKEKIDRRSGKKLEDGPKFLKSGDAAIVDMVPGKPMCVESFSDYPP

LGRFAVRDMRQTVAVGVIKAVDKKAAGAGKVTKSAQKAQKAK

\section{Figure 3}

Sequence alignement of a fraction of the chromatogram of the $50 \mathrm{kD}$ HeLa protein trypsin digestion and human elongation factor I alpha.

was statistically significant $(\mathrm{p}<0.05)$ as compared to patients with acute infection. Sera samples from healthy controls showed no reactivity at the dilutions tested.

\section{Detection of antibodies by Western blot and sequence analysis}

Fourteen different HeLa bands, with molecular masses ranging from 20 to $100 \mathrm{kD}$, were detected by Western blot. Normal sera showed minimal if any reactivity with HeLa proteins. Twelve patients with acute Coxiella infections (57\%) showed antibodies that reacted with one to three different bands per sample. By contrast, twenty-five sera of patients with chronic Coxiella infections (75\%) showed antibody reactivities to a broad spectrum of up to seven different proteins. A predominant and consistent 50 $\mathrm{kD}$ band was observed in 14 of the patients with chronic infections (42\%) and in 3 of the acute cases (14\%) (Figure 2 ). No reactivity to this band was found in healthy controls. Sequence analysis of a fragment of this $50 \mathrm{kD}$ protein showed a 98\% homology with human elongation factor 1 alpha (Figure 3).

\section{Discussion}

It must be noted that the presence of natural autoantibodies is a normal feature in sera of healthy individuals and their presence may only be circumstantial or transitory. Such natural autoantibodies are usually present at low titre, have poor affinity for their corresponding antigen and usually belong to the IgM class. In autoimmune diseases, self-antigens are recognised by pathological autoantibodies with specificities that differ from those that may occur naturally in healthy humans [26]. 
As in other infectious diseases, some immunological aspects of the host response to Coxiella in patients with $\mathrm{Q}$ fever could be related to self-antigen responses. In our hands, the presence of PCA, ANA, dsDNA and ANCA does not seem to clearly correlate with any of our group of patients and could be only circumstantial. Only ASMA and CMA antibodies were found in a significant percentage of acute and chronically infected Q fever patients as compared to the normal population. In the literature, CMA have rarely been found in normal individuals and their presence has been associated with autoimmune myocarditis, idiopathic dilated cardiomyopathy or rheumatic carditis [33-37]. Many different specificities have been described but mitochondrial and contractile cytoplasmic proteins such as myosin or actin seem to be widely implicated $[33,38]$. CMA detection following microbial infections has been related to the release of antigens after tissue damage, but in some cases, as in chlamydia infections, Chagas disease, post-streptoccocal rheumatic fever or coxsackie myopericarditis, molecular homologies between host antigens and the etiological agent have been described $[11,18,21,25]$. CMA presence in the sera of $\mathrm{Q}$ fever patients without cardiac involvement was unexpected and suggested that they were not elicited by tissue damage. The possible existence of molecular homologies between coxiella and host antigens was studied by immunoblotting with human HeLa extracts. Results revealed that sera from most of the chronically infected patients and some of acute patients reacted strongly with a $50 \mathrm{kD}$ antigen. Preliminary results of the sequence analysis of an internal fragment of this protein showed molecular homology with human elongation factor 1 alpha. This ubiquitously expressed protein is phylogenetically conserved and an abundant member of the actin binding proteins family, responsible for binding the aminoacyl-tRNA to the ribosome during polypeptide elongation [39-41]. It co-localises intracellularly with the F-actin and is related to changes in the actin cytoskeleton. High levels of its expression are correlated with cell proliferation, oncogenic transformation, metastasis and are been considered a molecular market for injured muscle $[42,43]$ and it has been described as a common IgG autoantibody target in atopic dermatitis and Felty's syndrome $[44,45]$.

This preliminary study shows that, as in other infectious diseases, patients with Coxiella infections have an autoantibody profile with specificities that resemble those found in autoimmune disease. Further studies would be needed to evaluate whether these findings could only be considered a circumstantial evidence of natural response or have pathological implications.

\section{Acknowledgements}

We would like to thank A.I. Marina, J. Gonzalez, J.M. Vazquez of the Department of Quimica de Proteinas of Centro de Biología Molecular of the University Autónoma de Madrid for performing amino acid sequencing and M.J. Ramos for technical assistance.

This work was supported by a grant from the Fondo de Investigaciones Sanitarias (Expt n 97/0191).

\section{References}

I. Madariaga MG, Rezai K, Trenholme GM, Weinstein RA: Q fever: a biological weapon in your backyard. Lancet Infect Dis 2003, 3(II):709-72I.

2. Maurin M, Raoult D: Q Fever. Clin Microbiol Rev 1999, I 2:51 8-553.

3. Harris RJ, Storm PA, Lloyd A, Arens M, Marmion BP: Long-term persistence of Coxiella burnetii in the host after primary $Q$ fever. Epidemiol Infect 2000, I 24:543-549.

4. Raoult D, Marrie TJ, Mege JL: Natural history and pathophysiology of $\mathbf{Q}$ fever. Lancet Infect Dis 2005, 5:219-226.

5. Arricau-Bouvery $\mathbf{N}$, Rodolakis $A$ : Is $\mathbf{Q}$ fever and emerging or reemerging zoonosis? Vet Res 2005, 36:327-349.

6. Raoult D, Tissot-Dupont H, Foucault C, Gouvernet J, Fournier PE, Bernit E, Stein A, Nesri M, Harle J, Weiller PJ: Q fever I 985-I998. Medicine 2000, 79: 109-I23.

7. Bossi P, Tegnell A, Baka A, van Loock F, Hendriks J, Werner A, Maidhof H, Gouvras G: Bichat Guidelines for the Clinical Management of $\mathbf{Q}$ Fever and Bioterrorism-Related $\mathbf{Q}$ Fever. Eurosurveillance 2004, 9(I 2EI9-E20 [http://www.eurosurveil lance.org].

8. Fournier PE, Marrie TJ, Raoult D: Diagnosis of $\mathbf{Q}$ fever. J Clin Microbiol 1998, 36:1823-1933.

9. Dighiero G, Rose NR: Critical self-epitopes are key to the understanding of self-tolerance and autoimmunity. Immunol Today 1999, 20:423-428.

10. Klareskog L, Lorentzen J, Padyukov L, Alfredsson L: Genes and environment in arthritis: can RA be prevented? Arthritis Res 2002, 4:31-36.

II. Kamradt T, Goggel R, Erg KJ: Induction, exacerbation and inhibition of allergic and autoimmune diseases by infection. Trends Immunol 2005, 26:260-267.

12. Slev PR, Potts WK: Disease consequences of pathogen adaptation. Curr Opin Immunol 2002, |4:609-6|4.

13. Behar SM, Porcelli SA: Mechanisms of autoimmune disease induction. The role of the immune response to microbial pathogens. Arthritis Rheum 1995, 38:458-476.

14. Small PLC, Ramakrishnan L, Falkow S: Remodelling schemes of intracellular pathogens. Science 1994, 263:637-639.

15. Aichele P, Bachmann MF, Hengartner H, Zinkernagel RM: Immunopathology or organ-specific autoimmunity as a consequence of virus infection. Immunol Rev 1996, I 52:2 I-45.

16. Naucler CS, Larsson S, Moller E: A novel mechanism for virusinduced autoimmunity in humans. Immunol Rev 1996, I52:| $75-192$.

17. Von Herrath MG, Oldstone MBA: Virus-induced autoimmune disease. Curr Opin Immunol 1996, 8:878-885.

18. Kaplan D, Ferrari I, Lopez Bergami P, Mahler E, Levitus G, Chiale P, Hoebekes J, Van Regenmortel MHV, Levin MJ: Antibodies to ribosomal $\mathbf{P}$ proteins of Trypanosoma cruzi in Chagas disease possess functional autoreactivity with heart tissue and differ from anti-P autoantibodies in lupus. Proc Natl Acad USA 1997, 94: $10301-10306$.

19. Rose NR, Herskowitz A, Neumann DA, Neu N: Autoimmune myocarditis: a paradigm of post-infection autoimmune disease. Immunol Today 1988, 9: I 17-120.

20. Wolfgram LJ, Beisel KW, Rose NR: Heart-specific autoantibodies following murine Coxsackievirus B3 myocarditis. J Exp Med 1965, I6I:III2-II2I.

21. Kaplan MH, Meyeserian M: An immunological cross-reaction berween Group-A Streptococcal cells and human heart tissue. Lancet 1962, I:706-710.

22. Isenberg DA, Maddison P, Swana G, Skinner RP, Swana M, Jones M, Addison I, Dudeney C, Shall S, Roiey AEL, Shoenfeld Y: Profile of autoantibodies in the serum of patients with tuberculosis, Klebsiella and other Gram-negative infections. Clin Exp Immunol 1987, 67:516-523.

23. Vaughan JH, Valbracht JR, Nguyen MD, Handley HH, Smith RS, Patrick $\mathrm{K}$, Rhodes GH: Epstein-Barr virus-induced autoimmne responses. I Immunoglobulins $M$ autoantibodies to proteins 
mimicking and not mimicking Epstein-Barr Virus Nuclear Antigen I. J Clin Invest 1995, 95: 1306-1315.

24. Vaughan JH, Nguyen MD, Valbracht JR, Smith RS, Patrick K, Rhodes $\mathrm{GH}$ : Epstein-Barr virus-induced autoimmune responses. II Immunoglobulin $G$ autoantibodies to mimicking and notmimicking epitopes. Presence in autoimmune disease. J Clin Invest 1995, 95: I316-1327.

25. Bachmaier K, Neu N, de la Maza LM, Pal S, Hassel A, Penninger JM: Chlamydia infections and heart disease linked through antigenic mimicry. Science 1999, 283:1335-1339.

26. Rose NR, Bona C: Defining criteria for autoimmune diseases (Witebsky's postulates revisited). Immunol Today 1993, 1 4:426-430.

27. Levy P, Raoult D, Razongles J]: $\mathbf{Q}$ fever and autoimmunity. Eur J Epidemiol 1989, 5:447-453.

28. Camacho MT, Outschoorn I, Téllez A: Role of IgG subclasses in $\mathbf{Q}$ fever. Eur J Clin Microbiol Infect Dis 1995, 14:1070-1075.

29. Camacho MT, Outschoorn I, Echevarría C, Kovachova E, Yebra M, Maté I, Auffray P, Téllez A: Distribution of IgA subclass response to C.burnetii in patients with acute and chronic $Q$ fever. Clin Immunol Immunopathol 1998, 88:80-83.

30. Tan EM: Relationship of nuclear staining patterns with precipitating antibodies in systemic lupus erythematosus. J Lab Clin Med 1967, 70:800-812.

31. Laemmli UK: Cleavage of structural proteins during assembly of thew head of bacteriophage T4. Nature 1970, 227:680-685.

32. Garcia-Lerma JG, Mendoza AZ, Ramos MJ, Sequi J: Evaluation of Recombinant Ro/SSA, La/SSB, Sm and UI RNP Autoantigens in Clinical Diagnosis. J Clin Lab Anal 1995, 9:52-58.

33. Scheerder I, Buyzere M, Algoed L, De Lange M, Delanghe J, Bogaert AM, Clement DL: Characteristic anti-heart antibody patterns in post-cardiac injury syndrome, endocarditis and acute myocarditis. Eur Heart J 1987, 8:237-238.

34. Caforio AL, Bonifacio E, Stewart JT, Neglia D, Parodi O, Bottazzo GF, McKenna WJ: Novel organ-specific circulating cardiac autoantibodies in dilated cardiomyopathy. J Am Coll Cardiol 1990, I 5: 1527-I534.

35. Caforio AL, Mahon NJ, McKenna WJ: Cardiac autoantibodies to myosin and other heart-specific autoantigens in myocarditis and dilated cardiomyopathy. Autoimmunity 200 I, 34:199-204.

36. Latif N, Baker C, Dunn MJ, Rose ML, Brady P, Yacoub MH: Frequency and specificity of antiheart antibodies in patients with dilated cardiomyopathy detected using SDS-PAGE and Western-blotting. J Am Coll Cardiol 1993, 22:1378-I384.

37. Tontsch D, Pankuweit S, Maish B: Autoantibodies in the sera of patients with rheumatic heart disease: characterization of myocardial antigens by two-dimensional immunoblotting and $\mathbf{N}$-terminal sequence analysis. Clin Exp Immunol 2000, I 2 I:270-274.

38. Neu N, Rose NR, Beisel KW, Herskowitz A, Gurri-Glass G, Craig SW: Cardiac Myosin induces myocarditis in genetically predisposed mice. J Immunol 1987, I39:3630-3636.

39. Moldave K: Discovery, resolution, purification and function of elongation factors. Methods Enzymol 1990, 182:809-8I8.

40. Negrutskii BS, El'skaya AV: Eukaryotic translation elongation factor I alpha: structure, expression, functions and possible role in aminoaciyl-tRNA channelling. Prog Nucleic Acid Res Mol Biol 1998, 60:47-78.

4I. Bektas M, Guncer B, Guven C, Nurten R, Bermek E: Actin-an inhibitor of eukariotic alongation factor activities. Biochem Biophys Res Commun 2004, 3 17:106I-1066.

42. Edmonds BT, Wyckoff J, Yeung Y, Wang Y, Stanley R, Jones J, Segall J, Condeelis J: Elongation factor- $\mathrm{I} \alpha$ is an overexpressed actin binding proteins in metastatic rat mammary adenocarcinoma. J Cell Sci 1996, 109:2705-27I4.

43. Khalyfa A, Carlson BM, Carlson JA, Wang E: Toxin injury-dependent switched expression between EF-I alpha and its sister SI in rat skeletal muscle. Dev Dyn 1999, 2 16:267-273.

44. Ditzel HJ, Masaki Y, Nielsen H, Farnaes L, Burton RD: Clonning and expression of a novel human antibody-antigen pair associated with Felty's syndrome. PNAS 2000, 97:9234-9239.

45. Ohkouchi K, Mizutani H, Tanaka M, Takahashi M, Nakashima K, Shimizu M: Anti-elongation factor-I $\alpha$ autoantibody in adult athopic dermatitis patients. Intern Immunol 1999, I I:I635-1640.

\section{Publish with Biomed Central and every scientist can read your work free of charge}

"BioMed Central will be the most significant development for disseminating the results of biomedical research in our lifetime. "

Sir Paul Nurse, Cancer Research UK

Your research papers will be:

- available free of charge to the entire biomedical community

- peer reviewed and published immediately upon acceptance

- cited in PubMed and archived on PubMed Central

- yours - you keep the copyright

Submit your manuscript here:

http://www.biomedcentral.com/info/publishing_adv.asp
BioMedcentral 